\title{
Correction to: Does globalization affect the green economy and environment? The relationship between energy consumption, carbon dioxide emissions, and economic growth
}

\author{
Muhammad Khalid Anser ${ }^{1} \cdot$ Muhammad Usman $^{2} \cdot$ Danish Iqbal Godil $^{3} \cdot$ Malik Shahzad Shabbir $^{4} \cdot$ Arshian Sharif $^{5,6}$. \\ Mosab Ismail Tabash ${ }^{7} \cdot$ Lydia Bares Lopez $^{8}$
}

Published online: 2 July 2021

(C) Springer-Verlag GmbH Germany, part of Springer Nature 2021

\section{Correction to: Environmental Science and Pollution Research https://doi.org/10.1007/s11356-021-14243-4}

The correct presentation of the 6th Author name is shown in this paper.

The original article has been corrected.

Publisher's note Springer Nature remains neutral with regard to jurisdictional claims in published maps and institutional affiliations.

The online version of the original article can be found at https://oi.org/ $10.1007 / \mathrm{s} 11356-021-14243-4$

Malik Shahzad Shabbir

Shahzad.shabbir@ibnhaldun.edu.tr

Muhammad Khalid Anser

mkhalidrao@xauat.edu.cn

Muhammad Usman

musman@s3h.nust.edu.pk

Danish Iqbal Godil

danishiqbal.bukc@bahria.edu.pk

Arshian Sharif

arshian.aslam@gmail.com

Mosab Ismail Tabash

mosab.tabash@aau.ac.ae

Lydia Bares Lopez

Lydia.bares@uca.es
1 School of Public Administration, Xi'an University of Architecture and Technology, Xi'an, Shaanxi, China

2 Department of Management Sciences, National University of Science and Technology, Islamabad, Pakistan

3 Business Studies Department, Bahria Business School, Bahria University Karachi Campus, Karachi, Pakistan

4 Department of Civilization studies, Ibn Haldun University, Başakşehir, Turkey

5 Othman Yeop Abdullah Graduate School of Business, Universiti Utara Malaysia, Sintok, Malaysia

6 Department of Business Administration, Eman Institute of Management and Sciences, Karachi, Pakistan

7 College of Business, Al Ain University, Al Ain, United Arab Emirates

8 Department of Economics, University of Cadiz, Cadiz, Spain 